\title{
Up-Regulation of FGF23 Release by Aldosterone
}

Bingbing Zhang ${ }^{1}$, Anja T. Umbach ${ }^{1}$, Hong Chen ${ }^{1}$, Jing Yan ${ }^{1}$, Hajar Fakhri ${ }^{1}$, Abul Fajol ${ }^{1}$, Madhuri S. Salker ${ }^{1}$, Daniela Spichtig ${ }^{2}$, Arezoo Daryadel ${ }^{2}$, Carsten A. Wagner ${ }^{2}$, Michael Föller $^{3}$, Florian Lang ${ }^{1}$

${ }^{1}$ Departments of Physiology, University of Tübingen, Gmelinstr. 5, 72076 Tübingen, Germany ${ }^{2}$ Institute of Physiology, University of Zürich, Winterthurerstr. 190, CH-8057 Zürich, Switzerland and NCCR Kidney.CH, Switzerland

${ }^{3}$ Institute of Agricultural and Nutritional Sciences, Martin Luther University Halle-Wittenberg, Von-Danckelmann-Platz 2, 06120 Halle (Saale), Germany

Correspondence to:

Prof. Dr. Florian Lang

Physiologisches Institut der Universität Tübingen, Gmelinstr. 5, D-72076 TÜBINGEN Tel: +49 707129 72194, Fax: +49 707129 5618, e-mail: florian.lang@ uni-tuebingen.de

short title: Aldosterone sensitive FGF23 release 


\begin{abstract}
The fibroblast growth factor (FGF23) plasma level is high in cardiac and renal failure and is associated with poor clinical prognosis of these disorders. Both diseases are paralleled with hyperaldosteronism. Excessive FGF23 levels and hyperaldosteronism are further observed in Klotho-deficient mice. The present study explored a putative aldosterone sensitivity of Fgf23 transcription and secretion and the putative involvement of the aldosterone sensitive serum \& glucocorticoid inducibe kinase SGK1 and SGK1 sensitive transcription factor NFאB and store operated $\mathrm{Ca}^{2+}$ entry (SOCE). Serum FGF23 levels were determined by ELISA in mice following sham treatment or exposure to deoxycorticosterone acetate (DOCA) or salt depletion. In osteoblastic UMR106 cells transcript levels were quantified by qRT-PCR, cytosolic $\mathrm{Ca}^{2+}$ concentration utilizing Fura-2-fluorescence, and SOCE from $\mathrm{Ca}^{2+}$ entry following store depletion by thapsigargin. As a result, DOCA treatment and salt depletion of mice elevated the serum C-terminal FGF23 concentration. In UMR106 cells aldosterone enhanced and spironolactone decreased SOCE. Aldosterone further increased Fgf23 transcript levels in UMR106 cells, an effect reversed by mineralocorticoid receptor blockers spironolactone and eplerenone, SGK1 inhibitor EMD638683, NFאB-inhibitor withaferin A, and $\mathrm{Ca}^{2+}$ channel blocker YM58483. In conclusion, Fgf23 expression is up-regulated by aldosterone, an effect sensitive to SGK1, NFkB and store-operated $\mathrm{Ca}^{2+}$ entry.
\end{abstract}

\title{
Key words:
}

$1,25(\mathrm{OH})_{2} \mathrm{D}_{3}$; mineralocorticoid, spironolactone, SOCE, calcium, Orai1, NFאB 


\section{Introduction}

Regulation of calcium phosphate metabolism involves FGF23 (fibroblast growth factor 23), which is mainly released from bone cells [1]. FGF23 decreases formation and fosters inactivation of 1,25-dihydroxyvitamin $\mathrm{D}_{3}\left(1,25(\mathrm{OH})_{2} \mathrm{D}_{3}\right)$ by down-regulating renal $1 \alpha$ hydroxylase (Cyp27b1) and up-regulating 25-hydroxyvitamin D 24-hydroxylase (Cyp24a1) [2]. FGF23 thus lowers serum levels of $1,25(\mathrm{OH})_{2} \mathrm{D}_{3}[3,4]$, which stimulates renal and intestinal phosphate and calcium transport[5,6]. FGF23 deficiency is followed by increase of plasma $1,25(\mathrm{OH})_{2} \mathrm{D}_{3}$ levels, hyperphosphatemia, and hypercalcemia leading to vascular calcification, rapid aging and a substantial decrease of the life span [2]. Vascular calcification is stimulated by hyperphosphatemia [7], a predictor of mortality [8] and by aldosterone [9], which similarly impacts on life span [9].

Excessive plasma FGF23 levels are observed and are associated with accelerated disease progression, morbidity and/or mortality in several clinical disorders including cardiac failure [10,11], acute renal failure [12], chronic kidney disease [11,13,14], diabetic nephropathy [15] and hepatic failure [16]. The pathophysiological significance of enhanced FGF23 formation, has, however, remained ill-defined [17,18] and little is known about mechanisms accounting for the up-regulation of FGF23 release in these clinical disorders.

Most recently, Fgf23 transcription has been shown to be stimulated by an increase in the cytosolic $\mathrm{Ca}^{2+}$ concentration $\left(\left[\mathrm{Ca}^{2+}\right] \mathrm{i}\right)$ secondary to upregulation of store operated $\mathrm{Ca}^{2+}$ entry (SOCE) [19], which is triggered by depletion of intracellular $\mathrm{Ca}^{2+}$ stores [20]. SOCE is accomplished by the calcium release-activated channel (CRAC) moiety Orai1 (CRACM1) [21], which is activated by stromal interaction molecule 1 (STIM1) [22]. Expression and activity of Orai1 are up-regulated by the transcription factor NFKB [23].

Regulators of NFאB include mineralocorticoids [24,25]. In patients with non-ischemic cardiac disease and early chronic kidney disease high FGF23 plasma levels are associated with high plasma aldosterone concentrations [11].

The present study explored whether aldosterone modifies FGF23 release and, if so, whether the effect involves NFkB and $\mathrm{Ca}^{2+}$ entry.

\section{Materials and Methods}

\section{Animal experiments}

The animal experiments were conducted according to the German law for the welfare of animals and were approved by the state of Baden-Württemberg (Regierungspräsidium Tübingen). Fifty $\mu \mathrm{l}$ blood was collected from male and female C57BL/6 mice (8-20 weeks old). Then, mice were sham-treated or treated with a single s.c. injection of deoxycorticosterone acetate (DOCA; $100 \mathrm{mg} / \mathrm{kg}$ b.w.; Sigma, Schnelldorf, Germany) or spironolactone $(75 \mathrm{mg} / \mathrm{kg}$ b.w.; Sigma). Twelve hours after the injection, another $50 \mu \mathrm{l}$ blood was collected. For the effect of low salt diet on FGF23 release, male and female mice (2-13 months old) were fed a control diet or a low salt diet (containing $<0.2 \% \mathrm{Na}^{+}$and $\mathrm{Cl}^{-}$; Altromin, Lage, Germany) for a total of 7-14 days and subsequently $50 \mu \mathrm{l}$ blood were collected. Serum C-terminal FGF23 was determined with an ELISA kit (Immutopics, San Clemente, USA). Serum aldosterone and corticosterone were quantified by means of kits from IBL (Hamburg, Germany) according to the manufacturers' protocol.

\section{Cell culture}

UMR106 rat osteosarcoma cells were cultured in DMEM high glucose medium supplemented with $10 \%$ FCS and $1 \%$ penicillin/streptomycin under standard culture 


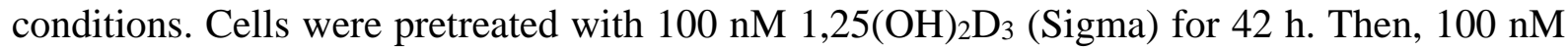
aldosterone (Sigma) was added without or with $10 \mu \mathrm{M}$ spironolactone (Sigma), $10 \mu \mathrm{M}$ eplerenone (Sigma), $100 \mathrm{nM}$ YM58483 (TOCRIS), $500 \mathrm{nM}$ withaferin A (TOCRIS), or $50 \mu \mathrm{M}$ SGK1 inhibitor EMD638683 (Merck Darmstadt, Germany) for $6 \mathrm{~h}$.

For the calcium measurements and the quantification of Orail transcripts, cells were treated with $100 \mathrm{nM}$ aldosterone (Sigma) or $10 \mu \mathrm{M}$ spironolactone (Sigma) for $24 \mathrm{~h}$ in serum-free medium.

\section{Quantification of $m R N A$ expression}

For the mRNA expression analysis in UMR106 cells, the final volume of the qRT-PCR reaction mixture was $20 \mu \mathrm{l}$ and contained: $2 \mu \mathrm{l}$ cDNA, $1 \mu \mathrm{M}$ of each primer, $10 \mu \mathrm{l}$ GoTaq Master Mix (Promega), and sterile water up to $20 \mu \mathrm{l}$. PCR conditions were $95^{\circ} \mathrm{C}$ for $3 \mathrm{~min}$, followed by 40 cycles of $95^{\circ} \mathrm{C}$ for $10 \mathrm{~s}, 58^{\circ} \mathrm{C}$ for $30 \mathrm{~s}$. Quantitative RT-PCR was performed on a BioRad iCycler iQTM Real-Time PCR Detection System (Bio-Rad Laboratories, Munich, Germany).

For the determination of Fgf23 transcripts in mouse bone, bone was homogenized in liquid nitrogen using mortar and pestle. Total mRNA from bone was extracted with TRIzol (Invitrogen, Switzerland) followed by purification with RNeasy Mini Kit (Qiagen, Switzerland) according to the manufacturer's protocol. DNAse digestion was performed using the RNase-free DNAase Set (Qiagen, Switzerland). Total RNA extractions were analyzed for quality, purity, and concentration using the NanoDrop ND-1000 spectrophotometer (Wilmington, Germany). RNA samples were diluted to a final concentration of $100 \mathrm{ng} / \mu 1$ and cDNA was prepared using the TaqMan Reverse Transcriptase Reagent Kit (Applied Biosystems, Roche, Foster City, CA). In brief, in a reaction volume of $40 \mu 1,300 \mathrm{ng}$ of RNA was used as template and mixed with the following final concentrations of RT buffer $(1 \mathrm{x})$ : $\mathrm{MgCl}_{2}(5.5 \mathrm{mmol} / \mathrm{l})$, random hexamers $(2.5 \mu \mathrm{mol} / \mathrm{l})$, dNTP mix $(500 \mu \mathrm{mol} / \mathrm{l}$ each), RNase inhibitor $(0.4 \mathrm{U} / \mu \mathrm{l})$, multiscribe reverse transcriptase $(1.25 \mathrm{U} / \mu \mathrm{l})$, and RNAse-free water. Reverse transcription was performed with thermocycling conditions of $25^{\circ} \mathrm{C}$ for $10 \mathrm{~min}, 48^{\circ} \mathrm{C}$ for $30 \mathrm{~min}$, and $95^{\circ} \mathrm{C}$ for $5 \mathrm{~min}$ on a thermocycler (Biometra, Göttingen, Germany). Semi-quantitative real-time PCR (RT-PCR) was performed on the ABI PRISM 7700 Sequence Detection System (Applied Biosystems). Primers were chosen to spanning intron-exon boundaries to exclude genomic DNA contamination. Probes were labeled with the reporter dye FAM at the 5'-end and the quencher dye TAMRA at the 3'-end (Microsynth, Balgach, Switzerland). Real-time PCR reactions were performed using KAPA PROBE FAST qPCR Kit (Kapa Biosystems, USA).

The following primers were used:

Rat Tbp (TATA box-binding protein):

forward (5'-3'): ACTCCTGCCACACCAGCC

reverse (5'-3'): GGTCAAGTTTACAGCCAAGATTCA

Rat Fgf 23

forward (5'-3'): TGGCCATGTAGACGGAACAC

reverse (5'-3'): GGCCCCTATTATCACTACGGAG

Rat Orail

forward (5'-3'): CGTCCACAACCTCAACTCC

reverse (5'-3'): AACTGTCGGTCCGTCTTAT

Mouse Fgf 23

forward (5'-3'): TCGAAGGTTCCTTTGTATGGAT

reverse (5'-3'): AGTGATGCTTCTGCGACAAGT

Calculated mRNA expression levels were normalized to the expression levels of Tbp (in rat derived cell lines) or HPRT/18S (in mice) of the same cDNA sample. Relative quantification of gene expression was performed using the $\Delta \Delta \mathrm{Ct}$ method. 


\section{Measurement of intracellular $\mathrm{Ca}^{2+}$}

To determine the cytosolic $\mathrm{Ca}^{2+}$ concentration $\left(\left[\mathrm{Ca}^{2+}\right] \mathrm{i}\right)$, UMR106 cells were loaded with Fura-2/AM ( $2 \mu \mathrm{M}$, Molecular Probes, Göttingen, Germany) for $15 \mathrm{~min}$ at $37^{\circ} \mathrm{C}$. Fluorescence measurements were carried out with an inverted phase-contrast microscope (Axiovert 100, Zeiss, Oberkochen, Germany). Cells were excited alternatively at 340 or $380 \mathrm{~nm}$ and the light was deflected by a dichroic mirror into either the objective (Fluar 40x/1.30 oil, Zeiss, Oberkochen, Germany) or a camera (Proxitronic, Bensheim, Germany). Emitted fluorescence intensity was recorded at $505 \mathrm{~nm}$. Data acquisition was accomplished by using specialized computer software (Metafluor, Universal Imaging Downingtown, USA). As a measure for the increase in the cytosolic $\mathrm{Ca}^{2+}$ concentration, the slope and peak of the changes in the $340 / 380 \mathrm{~nm}$ ratio were determined in each experiment.

To determine SOCE, intracellular $\mathrm{Ca}^{2+}$ was measured before and after removal of extracellular $\mathrm{Ca}^{2+}$ (and addition of $0.5 \mathrm{mM}$ EDTA), followed by addition of thapsigargin (1 $\mu \mathrm{M}$ ) and subsequent re-addition of extracellular $\mathrm{Ca}^{2+}$ to Ringer solution, composed of (in $\mathrm{mM}$ ): $125 \mathrm{NaCl}, 5 \mathrm{KCl}, 1.2 \mathrm{MgSO}_{4}, 32.2 \mathrm{HEPES}\left(\mathrm{NaOH} / \mathrm{pH}\right.$ 7.4), $2 \mathrm{Na}_{2} \mathrm{HPO}_{4}, 0$ or $2 \mathrm{CaCl}_{2}$ and 0.5 or 0 EGTA, respectively, and 5 glucose.

\section{Immunofluorescence}

UMR106 cells treated with $100 \mathrm{nM}$ aldosterone were cultured on 4-well chamber slides (Thermo scientific), washed, and fixed with $4 \%$ paraformaldehyde for $30 \mathrm{~min}$ at room temperature. For blocking unspecific binding, UMR106 cells were incubated with 3\% Albumin Fraction V (Carl Roth, Karlsruhe, Germany), 5\% normal goat serum (Sigma, Schnelldorf, Germany), and $0.5 \%$ Triton in PBS (PAA, Cölbe, Germany) for 30 min at room temperature. Then, the cells were exposed to rabbit anti-p65 (1:1000, Genetex, Irvine, USA) at $4{ }^{\circ} \mathrm{C}$ in a humidified chamber overnight. The cells were rinsed four times with PBS and incubated with DyLight ${ }^{\circledR}$ 488-conjugated goat anti-rabbit antibody (1:3000, BIOZOL, Eching, Germany) for $1 \mathrm{~h}$ at room temperature. After four washing steps the nuclei were stained with DRAQ-5 dye (1:400; BIOZOL) for $30 \mathrm{~min}$ at room temperature. The slides and coverslips were mounted with FluorSave ${ }^{\mathrm{TM}}$ Reagent (Calbiochem, Darmstadt, Germany). Images were taken on a LSM 5 EXCITER confocal laser scanning microscope (Zeiss, Germany) with a water-immersion Plan-Neofluar 40×/1.3 NA differential interference contrast and analyzed with the instrument's software.

\section{Statistics}

Data are provided as means \pm SEM, $n$ represents the number of independent experiments. All data were tested for significance using unpaired Student $t$-test or ANOVA. Only results with $p<0.05$ were considered statistically significant.

\section{Results}

In order to test for an effect of mineralocorticoids on FGF23 release, a single dose of DOCA $(100 \mathrm{mg} / \mathrm{kg}$ b.w. s.c.) or vehicle was injected into wild type mice. Twelve hours later the serum C-terminal FGF23 (cFGF23) level was determined. As illustrated in Fig. 1A, the injection of DOCA was followed by a marked and significant increase in the serum cFGF23 concentration. In a second series of experiments, mice were fed a low salt diet. As expected, this diet induced an elevation of the serum aldosterone level $(889 \pm 217 \mathrm{pg} / \mathrm{ml} ; \mathrm{n}=5)$ compared to standard chow-fed mice $(268 \pm 27 \mathrm{pg} / \mathrm{ml} ; \mathrm{n}=5 ; \mathrm{p}<0.01)$. The diet did not significantly affect the serum corticosterone level (low salt diet: $162 \pm 32 \mathrm{ng} / \mathrm{ml} ; \mathrm{n}=5$; standard chow: $120 \pm 31$ $\mathrm{ng} / \mathrm{ml} ; \mathrm{n}=5$ ). As illustrated in Fig $1 \mathrm{~B}$, the low salt diet also elevated the serum concentration of 
C-terminal FGF23. The main site of FGF23 formation is the bone. Accordingly, we found a higher level of Fgf 23 transcripts in bone from DOCA-treated mice compared to untreated mice (Fig. 1C). Treatment with spironolactone (12 h, $75 \mathrm{mg} / \mathrm{kg} \mathrm{b.w.)} \mathrm{did,} \mathrm{however,} \mathrm{not} \mathrm{significantly}$ influence the serum FGF23 concentration (control: $201 \pm 6 \mathrm{pg} / \mathrm{ml}, \mathrm{n}=5$; spironolactone: $332 \pm$ $65 \mathrm{pg} / \mathrm{ml}, \mathrm{n}=5$ ). Similarly, spironolactone treatment did not block the increase in serum FGF23 induced by low-salt diet (serum FGF23 before low-salt diet: $134 \pm 15$ pg/ml; serum FGF23 after two weeks of low-salt diet: $194 \pm 13 \mathrm{pg} / \mathrm{ml} ; \mathrm{n}=8 ; \mathrm{p}<0.01$ ).

Fluorescence optics was employed to test whether aldosterone modifies the intracellular $\mathrm{Ca}^{2+}$ concentration $\left(\left[\mathrm{Ca}^{2+}\right]_{i}\right)$. Store-operated $\mathrm{Ca}^{2+}$ entry (SOCE) requires depletion of intracellular $\mathrm{Ca}^{2+}$ stores which was accomplished by inhibition of the sarcoendoplasmic $\mathrm{Ca}^{2+}$ ATPase (SERCA) with thapsigargin $(1 \mu \mathrm{M})$ in the absence of extracellular $\mathrm{Ca}^{2+}$. SOCE was estimated from the increase in $\left[\mathrm{Ca}^{2+}\right]_{i}$ following re-addition of extracellular $\mathrm{Ca}^{2+}$. UMR106 cells were treated with aldosterone or the mineralocorticoid receptor antagonist spironolactone and intracellular $\mathrm{Ca}^{2+}$ concentrations $\left(\left[\mathrm{Ca}^{2+}\right]_{i}\right)$ were determined prior to and following removal of extracellular $\mathrm{Ca}^{2+}$, addition of thapsigargin, and re-addition of extracellular $\mathrm{Ca}^{2+}$. As illustrated in Fig. 2A-C, aldosterone did not significantly modify the thapsigargin-induced increase in $\left[\mathrm{Ca}^{2+}\right] \mathrm{i}$ but significantly enhanced the elevation of $\left[\mathrm{Ca}^{2+}\right]$ i following re-addition of extracellular $\mathrm{Ca}^{2+}$. The aldosterone antagonist spironolactone did not significantly modify the thapsigargin-induced increase in $\left[\mathrm{Ca}^{2+}\right]$, but significantly blunted the increase in $\left[\mathrm{Ca}^{2+}\right]_{i}$ following re-addition of extracellular $\mathrm{Ca}^{2+}$ (Fig. 2D-F).

A further series of experiments explored whether the influence of aldosterone and spironolactone on $\mathrm{Ca}^{2+}$ signaling in UMR106 cells was involved in the transcriptional regulation of Fgf23. Aldosterone (Fig. 3A) significantly elevated the Orai1 transcript level in UMR106 cells. Moreover, aldosterone up-regulated the transcription of Fgf23, an effect virtually abrogated by spironolactone, the Orai inhibitor YM58483, or the NFkB inhibitor withaferin A (Fig. 3B). The dose-response curve of the aldosterone effect on FGF23 is shown in Fig 3C. The aldosterone antagonist eplerenone similarly reversed the aldosterone effect on Fgf23 (Fig. 3D). Immunofluorescence confirmed activation of NFKB by aldosterone in UMR106 cells (Fig. 3E).

A possible mediator of the aldosterone effect on Orail is SGK1 which has been shown to up-regulate this channel. Employing qRT-PCR we indeed found a positive effect of aldosterone on the Sgk1 transcript level in UMR106 cells (control: $0.73 \pm 0.04$ a.u., $n=12 ; 100 \mathrm{nM}$ aldosterone: $1.02 \pm 0.05$ a.u., $\mathrm{n}=12 ; \mathrm{p}<0.001$ ). Moreover, aldosterone failed to stimulate $\mathrm{Fgf} 23$ expression in the presence of a SGK1 inhibitor (Fig. 3F).

The dose effects of mineralocorticoid antagonism with spironolactone or eplerenone are displayed in Fig. 4A and 4B, respectively. Notably, the effect of higher aldosterone concentrations on FGF23 transcription were also blocked by the glucocorticoid antagonist mifepristone (Fig. 4C).

\section{Discussion}

The present observations reveal that mineralocorticoids may contribute to the regulation of Fgf23 transcription and release in vivo. They further shed some light on the cellular mechanisms involved. According to previous observations [19] FGF23 release is stimulated by an increase in the cytosolic $\mathrm{Ca}^{2+}$ concentration $\left(\left[\mathrm{Ca}^{2+}\right]_{i}\right)$, which could be triggered by store operated $\mathrm{Ca}^{2+}$ entry (SOCE). Aldosterone increased and spironolactone decreased SOCE and thus modified transcription of Fgf23. SOCE is mediated by isoforms of the channel Orai (CRAC) [21], which are activated upon store depletion by STIM1 and STIM2 [22]. UMR106 cells express high levels of Orai1 and STIM2 [19]. The expression of Orai1 is stimulated by the transcription factor NFkB [23], which thus impacts on Fgf23 expression [19]. Aldosterone has previously been shown to up-regulate NFkB $[24,26]$. The present study reveals that the effect of aldosterone on Fgf23 
transcript levels is abrogated by NFאB inhibitors. The present observations do, however, not rule out that NFkB plays a permissive role in the regulation of FGF23 expression and release.

As aldosterone is effective at concentrations as low as $1 \mathrm{nM}$, the effect of aldosterone is most likely - at least in part - due to stimulation of mineralocorticoid receptors. The effect of higher aldosterone concentrations is, however, blunted by the glucocorticoid antagonist mifepristone, an observation pointing also to an involvement of glucocorticoid receptors. Noteworthy, both, mineralocorticoid and glucocorticoid receptors upregulate the serum \& glucocorticoid inducible kinase (SGK1) which has been shown to induce Orai1-dependent $\mathrm{Ca}^{2+}$ entry by activating NFאB [27]. Along those lines, pharmacological SGK1 inhibition reversed the effect of aldosterone on Fgf23 expression. Spironolactone treatment, however, did not reverse the increase in serum FGF23 induced by low-salt diet. Thus, the possibility must be kept in mind that mechanisms other than mineralocorticoid receptor activation contribute to the up-regulation of FGF23 release during dehydration. Along those lines, renal klotho expression is not only down-regulated by mineralocorticoids but as well by ADH [28].

Chronic kidney disease [29-31], heart failure [32-34], diabetic nephropathy [35], and hepatic failure [34] are all characterized by hyperaldosteronism. According to the present observations, the high FGF23 plasma concentration in heart failure [10,11], acute renal failure [12], chronic kidney disease [11,13,14], diabetic nephropathy [15] and hepatic failure [16] could at least in part be secondary to the hyperaldosteronism associated with these diseases. The effect of aldosterone may at least partially be mediated by the serum \& glucocorticoid inducible kinase SGK1, which is up-regulated by aldosterone and during diabetes [36] and is known to up-regulate Orai1 [23].

In conclusion, aldosterone is a powerful stimulator of FGF23 formation in vitro and in vivo. Aldosterone is at least partially effective by $\mathrm{NF} \kappa \mathrm{B}$ dependent up-regulation of Orail with subsequent enhancement of store operated $\mathrm{Ca}^{2+}$ entry.

\section{Acknowledgements}

The authors acknowledge the technical assistance of E. Faber.

The study was supported by the Deutsche Forschungsgemeinschaft (La 315/15-1, Fo 695/1-1 and Fo 695/1-2) and the National Center for Competence in Research NCCR Kidney. CH financed by the Swiss National Science Foundation.

All authors disclose that they have no potential conflict of interest (e.g., consultancies, stock ownership, equity interests, patent-licensing arrangements, lack of access to data, or lack of control of the decision to publish).

\section{References}

[1] M. Hori, Y. Shimizu, S. Fukumoto, Minireview: fibroblast growth factor 23 in phosphate homeostasis and bone metabolism, Endocrinology 152 (2011) 4-10.

[2] T. Shimada, M. Kakitani, Y. Yamazaki, H. Hasegawa, Y. Takeuchi, T. Fujita, S. Fukumoto, K. Tomizuka, T. Yamashita, Targeted ablation of Fgf23 demonstrates an essential physiological role of FGF23 in phosphate and vitamin D metabolism, J Clin. Invest 113 (2004) 561-568.

[3] X. Bai, D. Miao, J. Li, D. Goltzman, A.C. Karaplis, Transgenic mice overexpressing human fibroblast growth factor 23 (R176Q) delineate a putative role for parathyroid hormone in renal phosphate wasting disorders, Endocrinology 145 (2004) 5269-5279.

[4] H. Saito, K. Kusano, M. Kinosaki, H. Ito, M. Hirata, H. Segawa, K. Miyamoto, N. Fukushima, Human fibroblast growth factor-23 mutants suppress Na+-dependent 
phosphate co-transport activity and 1alpha,25-dihydroxyvitamin D3 production, J Biol. Chem. 278 (2003) 2206-2211.

[5] A.J. Brown, J. Finch, E. Slatopolsky, Differential effects of 19-nor-1,25-dihydroxyvitamin $\mathrm{D}(2)$ and 1,25-dihydroxyvitamin $\mathrm{D}(3)$ on intestinal calcium and phosphate transport, $\mathbf{J}$ Lab Clin. Med. 139 (2002) 279-284.

[6] H. Murer, N. Hernando, I. Forster, J. Biber, Proximal tubular phosphate reabsorption: molecular mechanisms, Physiol Rev. 80 (2000) 1373-1409.

[7] C.M. Giachelli, Vascular calcification: in vitro evidence for the role of inorganic phosphate, J. Am. Soc. Nephrol. 14 (2003) S300-S304.

[8] M. Tonelli, F. Sacks, M. Pfeffer, Z. Gao, G. Curhan, Relation between serum phosphate level and cardiovascular event rate in people with coronary disease, Circulation 112 (2005) 2627-2633.

[9] J. Voelkl, I. Alesutan, C.B. Leibrock, L. Quintanilla-Martinez, V. Kuhn, M. Feger, S. Mia, M.S. Ahmed, K.P. Rosenblatt, O.M. Kuro, F. Lang, Spironolactone ameliorates PIT1-dependent vascular osteoinduction in klotho-hypomorphic mice, J Clin Invest 123 (2013) 812-822.

[10] C. Faul, A.P. Amaral, B. Oskouei, M.C. Hu, A. Sloan, T. Isakova, O.M. Gutierrez, R. Aguillon-Prada, J. Lincoln, J.M. Hare, P. Mundel, A. Morales, J. Scialla, M. Fischer, E.Z. Soliman, J. Chen, A.S. Go, S.E. Rosas, L. Nessel, R.R. Townsend, H.I. Feldman, M. St John Sutton, A. Ojo, C. Gadegbeku, G.S. Di Marco, S. Reuter, D. Kentrup, K. Tiemann, M. Brand, J.A. Hill, O.W. Moe, O.M. Kuro, J.W. Kusek, M.G. Keane, M. Wolf, FGF23 induces left ventricular hypertrophy, J Clin Invest 121 (2011) 4393-4408.

[11] M. Imazu, H. Takahama, H. Asanuma, A. Funada, Y. Sugano, T. Ohara, T. Hasegawa, M. Asakura, H. Kanzaki, T. Anzai, M. Kitakaze, Pathophysiological Impact of Serum Fibroblast Growth Factor 23 in Patients with Non-ischemic Cardiac Disease and Early Chronic Kidney Disease, Am J Physiol Heart Circ Physiol 10.1152/ajpheart.00331.2014 (2014) ajpheart 0033102014.

[12] M. Christov, Fibroblast growth factor 23 in acute kidney injury, Curr Opin Nephrol Hypertens 23 (2014) 340-345.

[13] M.C. Hu, K. Shiizaki, M. Kuro-o, O.W. Moe, Fibroblast growth factor 23 and Klotho: physiology and pathophysiology of an endocrine network of mineral metabolism, Annu Rev Physiol 75 (2013) 503-533.

[14] P. Evenepoel, B. Meijers, L. Viaene, B. Bammens, K. Claes, D. Kuypers, D. Vanderschueren, Y. Vanrenterghem, Fibroblast growth factor-23 in early chronic kidney disease: additional support in favor of a phosphate-centric paradigm for the pathogenesis of secondary hyperparathyroidism, Clin J Am Soc Nephrol 5 (2010) 1268-1276.

[15] C. Zanchi, M. Locatelli, A. Benigni, D. Corna, S. Tomasoni, D. Rottoli, F. Gaspari, G. Remuzzi, C. Zoja, Renal expression of FGF23 in progressive renal disease of diabetes and the effect of ace inhibitor, PLoS One 8 (2013) e70775.

[16] D. Prie, A. Forand, C. Francoz, C. Elie, I. Cohen, M. Courbebaisse, D. Eladari, D. Lebrec, F. Durand, G. Friedlander, Plasma fibroblast growth factor 23 concentration is increased and predicts mortality in patients on the liver-transplant waiting list, PLoS One 8 (2013) e66182.

[17] F. Lang, M. Föller, Enigmatic Cassandra: renal FGF23 formation in polycystic kidney disease., Kidney Int 85 (2014) 1260-1262.

[18] O.W. Moe, Fibroblast growth factor 23: friend or foe in uremia?, J Clin Invest 122 (2012) 2354-2356.

[19] Y.J. Zhang B., Umbach AT, Fakhri H, Fajol A, Schmidt S, Salker MS, Chen H, Alexander D, Spichtig D, Daryadel A, Wagner CA, Föller M, Lang F, NFкB-sensitive Orai1 expression in the regulation of FGF23 release, J Mol Med (Berl) in press (2015). 
[20] A.B. Parekh, Store-operated CRAC channels: function in health and disease, Nat Rev Drug Discov 9 (2010) 399-410.

[21] M. Prakriya, S. Feske, Y. Gwack, S. Srikanth, A. Rao, P.G. Hogan, Orai1 is an essential pore subunit of the CRAC channel, Nature 443 (2006) 230-233.

[22] C. Peinelt, M. Vig, D.L. Koomoa, A. Beck, M.J. Nadler, M. Koblan-Huberson, A. Lis, A. Fleig, R. Penner, J.P. Kinet, Amplification of CRAC current by STIM1 and CRACM1 (Orai1), Nat Cell Biol 8 (2006) 771-773.

[23] F. Lang, E. Shumilina, Regulation of ion channels by the serum- and glucocorticoid-inducible kinase SGK1, FASEB J 27 (2013) 3-12.

[24] Y. Terada, S. Ueda, K. Hamada, Y. Shimamura, K. Ogata, K. Inoue, Y. Taniguchi, T. Kagawa, T. Horino, T. Takao, Aldosterone stimulates nuclear factor-kappa B activity and transcription of intercellular adhesion molecule-1 and connective tissue growth factor in rat mesangial cells via serum- and glucocorticoid-inducible protein kinase-1, Clin Exp Nephrol 16 (2012) 81-88.

[25] C.J. Zhu, Q.Q. Wang, J.L. Zhou, H.Z. Liu, F. Hua, H.Z. Yang, Z.W. Hu, The mineralocorticoid receptor-p38MAPK-NFkappaB or ERK-Sp1 signal pathways mediate aldosterone-stimulated inflammatory and profibrotic responses in rat vascular smooth muscle cells, Acta Pharmacol Sin 33 (2012) 873-878.

[26] V. Vallon, A.W. Wyatt, K. Klingel, D.Y. Huang, A. Hussain, S. Berchtold, B. Friedrich, F. Grahammer, R.S. Belaiba, A. Gorlach, P. Wulff, J. Daut, N.D. Dalton, J. Ross, Jr., U. Flogel, J. Schrader, H. Osswald, R. Kandolf, D. Kuhl, F. Lang, SGK1-dependent cardiac CTGF formation and fibrosis following DOCA treatment, J Mol Med (Berl) 84 (2006) 396-404.

[27] F. Lang, A. Eylenstein, E. Shumilina, Regulation of Orai1/STIM1 by the kinases SGK1 and AMPK, Cell Calcium 52 (2012) 347-354.

[28] C. Tang, G. Pathare, D. Michael, A. Fajol, M. Eichenmuller, F. Lang, Downregulation of Klotho expression by dehydration, Am J Physiol Renal Physiol 301 (2011) F745-750.

[29] F. Lang, E. Ritz, J. Voelkl, I. Alesutan, Vascular calcification--is aldosterone a culprit?, Nephrol. Dial. Transplant. 28 (2013) 1080-1084.

[30] T.K. Ma, C.C. Szeto, Mineralocorticoid receptor antagonist for renal protection, Ren Fail 34 (2012) 810-817.

[31] E. Ritz, N. Koleganova, G. Piecha, Is there an obesity-metabolic syndrome related glomerulopathy?, Curr Opin Nephrol Hypertens 20 (2011) 44-49.

[32] A.S. Mihailidou, Aldosterone in heart disease, Curr Hypertens Rep 14 (2012) 125-129.

[33] M. Sarraf, A. Masoumi, R.W. Schrier, Cardiorenal syndrome in acute decompensated heart failure, Clin J Am Soc Nephrol 4 (2009) 2013-2026.

[34] R.W. Schrier, Water and sodium retention in edematous disorders: role of vasopressin and aldosterone, Am J Med 119 (2006) S47-53.

[35] R.W. Schrier, A. Masoumi, E. Elhassan, Aldosterone: role in edematous disorders, hypertension, chronic renal failure, and metabolic syndrome, Clin J Am Soc Nephrol 5 (2010) 1132-1140.

[36] F. Lang, C. Bohmer, M. Palmada, G. Seebohm, N. Strutz-Seebohm, V. Vallon, (Patho)physiological significance of the serum- and glucocorticoid-inducible kinase isoforms, Physiol Rev. 86 (2006) 1151-1178. 


\section{Figure Legends}

Fig. 1. Effect of aldosterone on the FGF23 serum level. A. Arithmetic means \pm SEM (n=9-11) of the serum FGF23 concentration in wild type mice sham-treated (white bar) or treated with a single DOCA injection (100 mg/kg b.w. s.c.) for $12 \mathrm{hrs}$ (black bar). B. Arithmetic means \pm SEM $(n=11)$ of the serum FGF23 concentration in wild type mice treated with normal diet (white bar) or with low salt diet for 7-14 days (black bar). C. Arithmetic means \pm SEM (n=4-5) of the relative Fgf23 mRNA abundance in wild type mice sham-treated (white bar) or treated with a single DOCA injection $(100 \mathrm{mg} / \mathrm{kg}$ b.w. s.c.) for $12 \mathrm{hrs}$ (black bar). $*(\mathrm{p}<0.05)$, $* *(\mathrm{p}<0.001), * * *(\mathrm{p}<0.001)$, indicate significant difference.

Fig. 2. Effect of aldosterone and spironolactone on SOCE. A,D. Representative original tracings showing intracellular $\mathrm{Ca}^{2+}$ concentrations $\left(\left[\mathrm{Ca}^{2+}\right] \mathrm{i}\right)$ in Fura-2/AM loaded UMR106 cells prior to and following removal of extracellular $\mathrm{Ca}^{2+}$, addition of the sarco-endoplasmic $\mathrm{Ca}^{2+}$ ATPase (SERCA) inhibitor thapsigargin $(1 \mu \mathrm{M})$ and readdition of extracellular $\mathrm{Ca}^{2+}$, all in the absence (open circles) and presence (closed circles) of aldosterone (A, $100 \mathrm{nM}, 24 \mathrm{~h})$, or spironolactone $(\mathbf{D}, 10 \mu \mathrm{M}, 24 \mathrm{~h})$. B,C,E,F. Arithmetic means \pm SEM of the peak (left) and slope (right) values of the $\left[\mathrm{Ca}^{2+}\right]_{i}$ increase following addition of thapsigargin reflecting $\mathrm{Ca}^{2+}$ release from intracellular stores $(\mathbf{B}, \mathbf{E})$ and of $\left[\mathrm{Ca}^{2+}\right]_{\mathrm{i}}$ increase following readdition of extracellular $\mathrm{Ca}^{2+}$ reflecting store operated $\mathrm{Ca}^{2+}$ entry $(\mathbf{C , F})$ in UMR106 cells incubated without (white bars) or with (black bars) aldosterone (B-C, $100 \mathrm{nM}, 24 \mathrm{~h}, \mathrm{n}=72-80$ ), or spironolactone $(\mathbf{E}-\mathbf{F}, 10 \mu \mathrm{M}, 24 \mathrm{~h}, \mathrm{n}=121-133) . *(\mathrm{p}<0.05), * * *(\mathrm{p}<0.001)$ indicate significant difference (student's t-test).

Fig.3. Effect of aldosterone on Fgf23 transcript levels in UMR106 cells with or without spironolactone, eplerenone, YM58483 and withaferin A. A. Arithmetic means \pm SEM $(n=18)$ of Orai1 mRNA abundance (relative to Tbp mRNA) in UMR106 cells incubated without (white bar) or with (black bar) aldosterone (100 nM, $24 \mathrm{~h})$. B. Arithmetic means \pm SEM $(n=7)$ of Fgf 23 mRNA abundance (relative to Tbp mRNA) in UMR106 cells incubated without (white bars) or with (black bars) aldosterone (100 nM, $6 \mathrm{~h}$ ) in the absence (left bars) or presence (right bars) of spironolactone $(10 \mu \mathrm{M})$ of Orai inhibitor YM58483 $(100 \mathrm{nM})$ or of NFKB inhibitor withaferin A $(500 \mathrm{nM})$. C. Arithmetic means \pm SEM (n=36-37) of Fgf23 mRNA abundance (relative to Tbp mRNA) in UMR106 cells incubated without (white bars) or with (black bars) aldosterone $(6 \mathrm{~h})$ at the indicated concentration. D. Arithmetic means \pm SEM $(n=11)$ of Fgf23 mRNA abundance (relative to Tbp mRNA) in UMR106 cells incubated without (white bars) or with (black bars) aldosterone $(100 \mathrm{nM}, 6 \mathrm{~h})$ in the absence (left bars) or presence (right bars) of eplerenone $(10 \mu \mathrm{M})$. E. Original immunofluorescence images demonstrating nuclear staining (Draq5; Red; left images), p65-specific staining (NFאB; Green middle images), and an overlay of both, nuclear and p65-specific staining (right images) in UMR106 cells incubated without (upper images) or with (lower images) aldosterone $(100 \mathrm{nM}, 24 \mathrm{~h})$ Scale bar: $20 \mu \mathrm{m}$. F. Arithmetic means \pm SEM $(\mathrm{n}=12)$ of Fgf23 mRNA abundance (relative to Tbp mRNA) in UMR106 cells incubated without (white bars) or with (black bars) aldosterone $(100 \mathrm{nM}, 6 \mathrm{~h})$ in the absence (left bars) or presence (right bars) of SGK1 inhibitor EMD638683 $(50 \mu \mathrm{M}) .{ }^{*}, * *, * * *(\mathrm{p}<0.05, \mathrm{p}<0.01, \mathrm{p}<0.001)$ indicate difference from control. \#\#\# $(\mathrm{p}<0.001)$ indicates difference from aldosterone alone.

Fig.4. Dose response relationship of mineralocorticoid and glucocorticoid antagonism with the aldosterone effect on Fgf23 transcription. Arithmetic means \pm SEM of Fgf 23 mRNA abundance (relative to Tbp mRNA) in UMR106 cells incubated with spironolactone $(A ; n=15)$, eplerenone $(\mathbf{B} ; n=9-11)$, or mifepristone $(\mathbf{C} ; n=4-6)$ at the indicated concentration without (white bars) or with (black bars) $100 \mathrm{nM}$ aldosterone $(6 \mathrm{~h}) . *, * *(\mathrm{p}<0.05, \mathrm{p}<0.01)$ indicate difference from control. \#, \#\#\# ( $<<0.05, \mathrm{p}<0.001)$ indicate difference from aldosterone alone. 


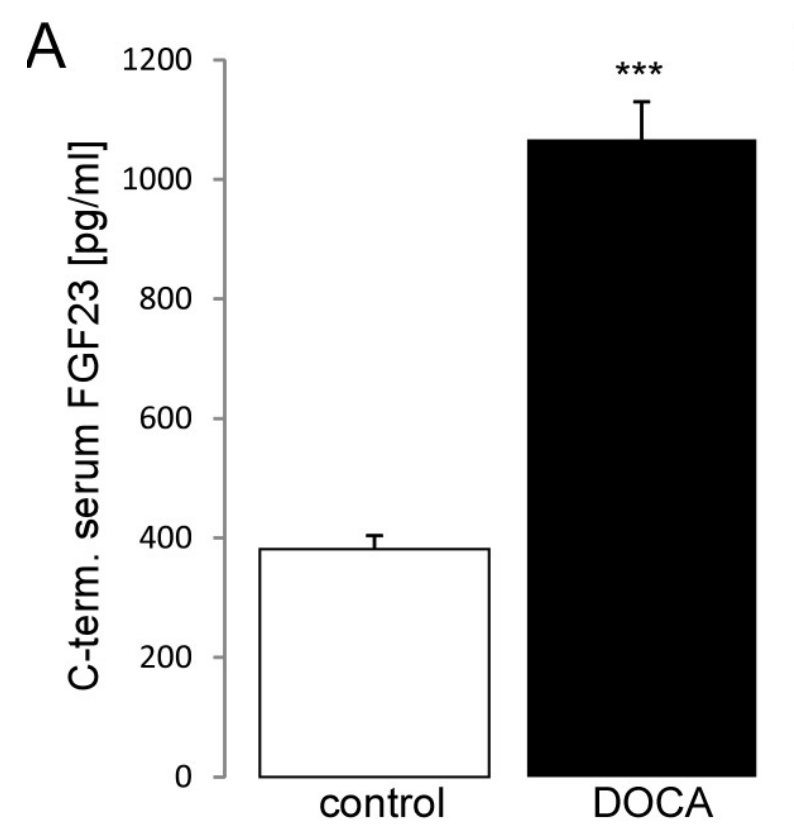

B

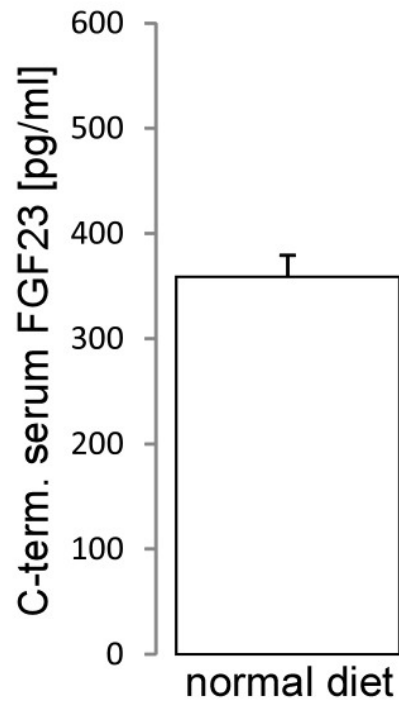

C

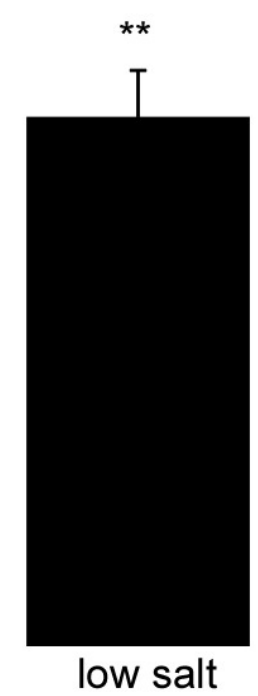

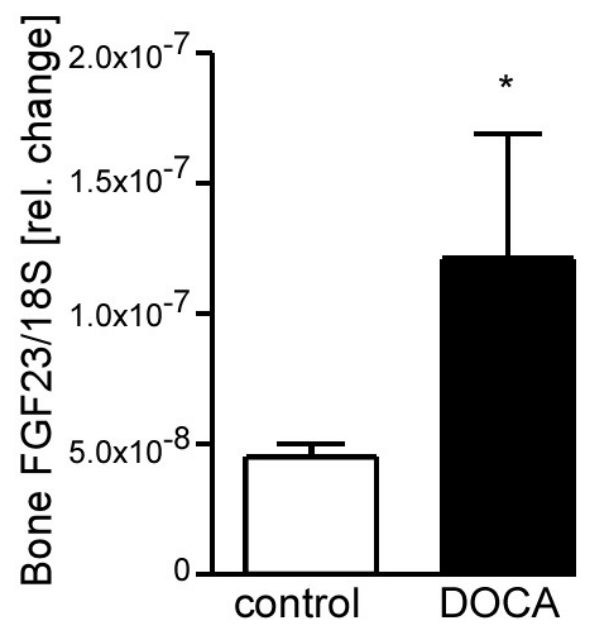

Figure 1 

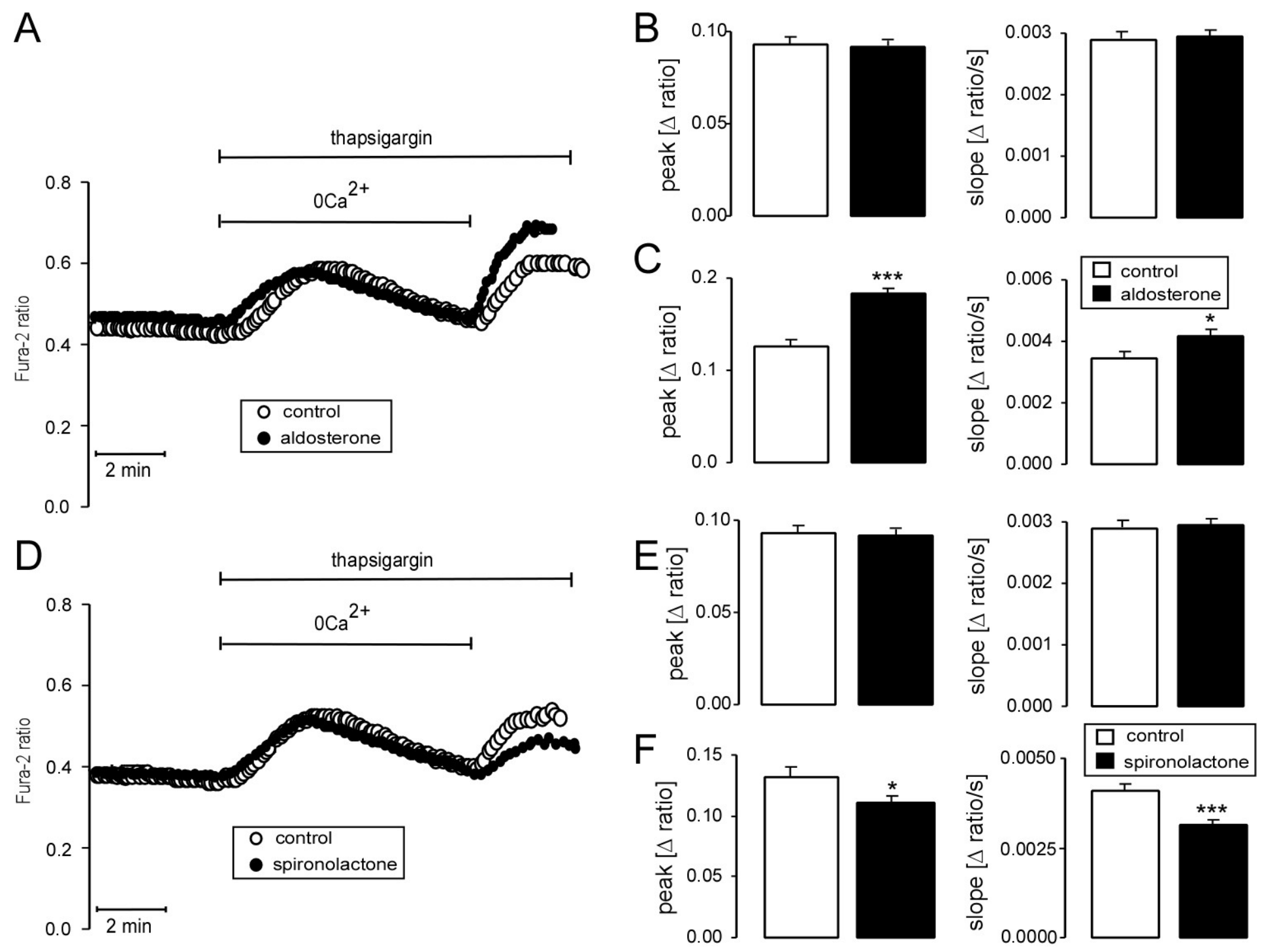

Figure 2 
A
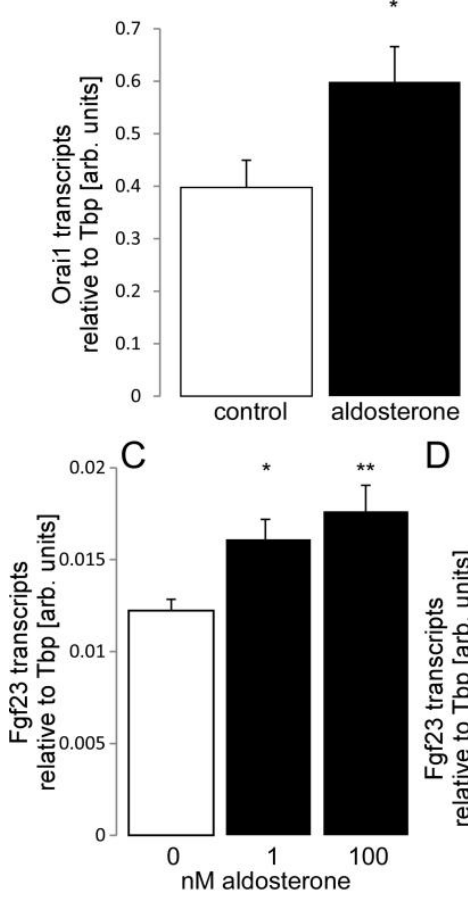

B

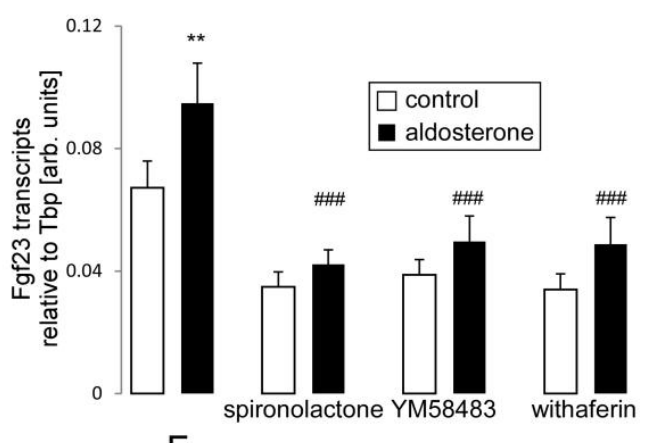

$\mathrm{F}$

$0.02 \quad \square$ control

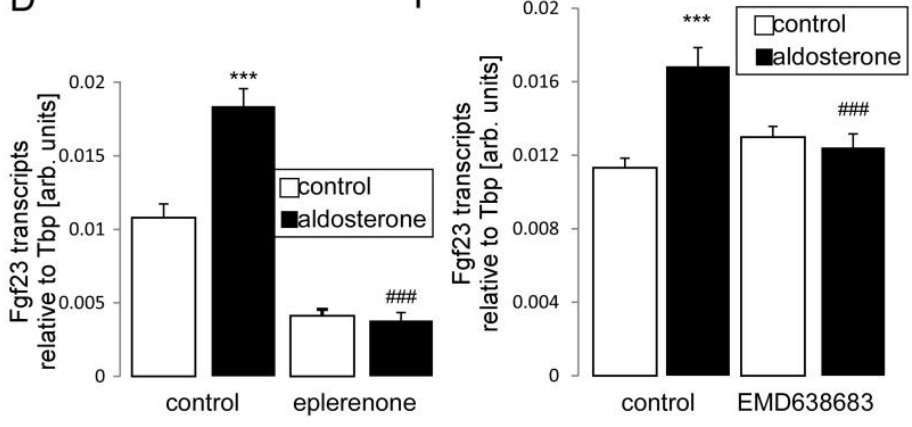

E
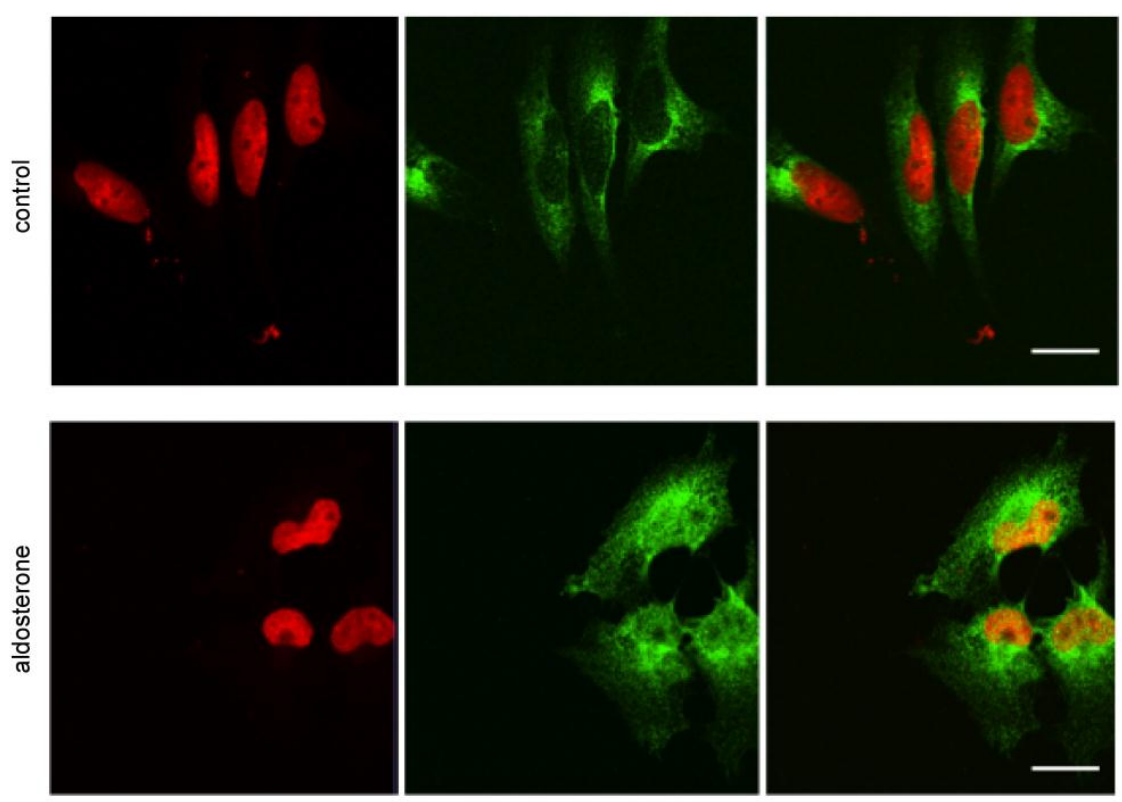

Figure 3 


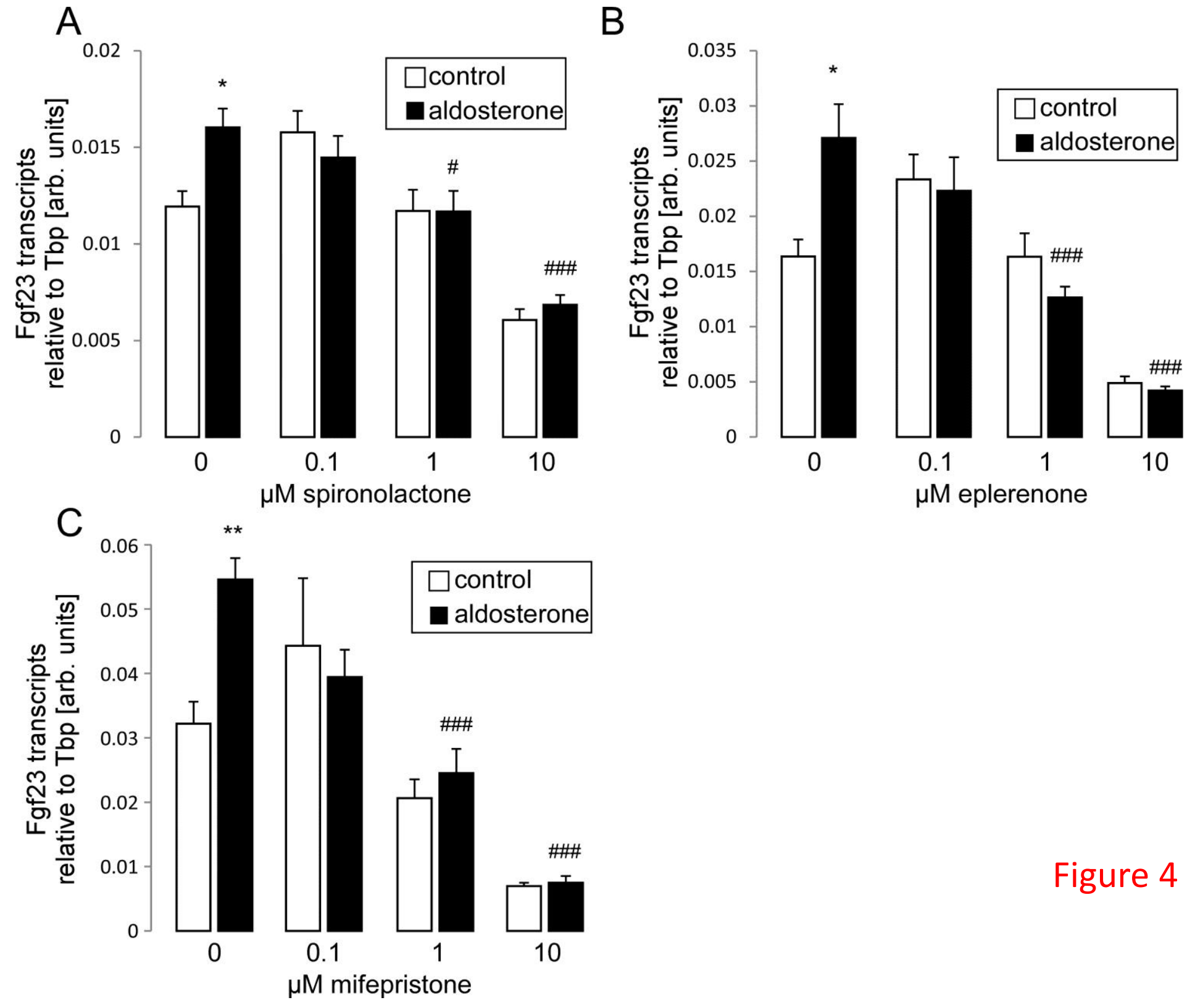

